\title{
Effect of Covid-19 related Stress on Marital Quality during Covid-19 Pandemic
}

\author{
Ni Nyoman Budiartini \\ Department of Psychology, Universitas Negeri Yogyakarta; \\ Jl. Colombo No.1 Sleman Daerah Istimewa Yogyakarta, 55281 \\ itsdiartini@gmail.com
}

\begin{abstract}
This research aimed to understand the effect of stress during the pandemic on marital quality in Bali. This research used a quantitative approach. Subjects involved in this research were 242 people who had been married for at least five years, with intact family conditions, and lived in Denpasar City, Bali. The instruments in this research were the COVID Stress Scale from Taylor (2020) and the Marital Quality scale arranged by Nurhayati (2017). The validity of this research used content validity by expert judgment. Reliability in the scale of this research used the Cronbach Alpha reliability coefficient. The COVID stress variable has a reliability of 0.934 , while the variable of marital quality has a reliability of 0.889 . As for the data analysis, descriptive analysis and simple linear regression analysis were used. Based on the data analysis, the regression coefficient was 0.028 and sig. 0.307, with the value of $\mathrm{R}$ square $=0.004$. The results showed that COVID stress does not affect the marital quality in Bali.
\end{abstract}

Keywords: marital quality, stress, COVID-19 pandemic

\section{Introduction}

According to Indonesian statute no. 1 1974, marriage is a bond between a man and a woman as husband and wife to form a happy and eternal family (household) based on the One God. Getting married and then building a happy and whole family and having healthy children is the dream of many people.

Marriage means uniting two individuals with different characters, both of whom must accept all the good and bad sides. They also have to be ready to go through the hardships and joys of life together until the end of life (Oktarina, Wijaya, \& Demartoto, 2015). Domestic life does not always run smoothly because sometimes there are conflicts that must be faced. Conflicts within the couple's relationship or conflicts from outside the partner, such as (workplace or family environment) if not appropriately resolved, can cause stress. High levels of stress in a marital relationship and the absence of problem-solving sources of stress can affect an individual's evaluation of the marriage itself.

The quality of marriage is a subjective evaluation of the relationship between husband and wife, high quality of marriage is related to smooth communication, good adjustment of the couple, a high level of happiness and a high level of marital satisfaction with the husband and wife household relationship (Herlanda, 2017). The quality of marriage is essential. The poor quality of a marriage not only gives unhappiness to the partner or the closest people involved in the marriage but can also 


\section{Effect of Covid-19 related Stress on Marital Quality \\ Ni Nyoman Budiartini}

lead to decreased productivity, psychological disorders, interpersonal conflicts or even divorce (Rahmah, Rahman, \& Fitriah, 2017).

Based on data summarized from the Denpasar Population and Civil Registry Office and the Denpasar City Religious Court, it was recorded that from 2015 to 2019, the divorce rate in Denpasar City continued to increase. In 2015, the number of legal divorce cases was 705 cases. Then in 2016, the number increased to 740 cases. In 2017, divorce cases in Denpasar had recorded as many as 717 cases, and in 2018, divorce cases in Denpasar again increased, which was recorded as many as 884 cases. Meanwhile, from January to December 6 2019, the number of divorce cases recorded at the Denpasar City Religious Court was 504 (Widyaswara, 2019).

Stress caused by financial conditions and stress, in general, can be associated with poor marital quality (Ellison, Henderson, Glenn, \& Harkrider, 2011). Clayson \& Frost (1984) found that low-stress blue-collar workers had significantly higher marital satisfaction than high-stressed workers. In addition, the stress in everyday relationships such as division of household tasks, different goals and annoying habits of spouses tend to affect marital communication and marital quality of couples (Ledermann, Bodenmann, Rudaz, \& Bradbury, 2010)

Randall \& Bondenmann (2009) divide stress into external stress and internal stress. Bondenmann (1995, 2005 in Randall \& Bondenmann 2009) and Story \& Bradbury (2004, in Randall \& Bondenmann 2009) state that external stress is the pressure outside the couple's relationship. This mainly includes interactions between partners and their social environment, which can indirectly affect the relationship, widespread stress between partners, and stresses on partners, such as arguments and conflicts.

High levels of external stress are associated with low levels of relationship satisfaction (Randall \& Bondenmann, 2009; Randall \& Bodenmann, 2017). The pandemic is one of the external stressors for couples and families, especially for those directly affected and get fatal consequences (for example, those who contract the COVID-19 disease, become unemployed or experience financial losses). According to Setiawan \& Rahmat (2011), there is a significant relationship between socioeconomic status and stress levels in young couples.

In addition to having an impact on financial stress, COVID-19 also impacts the psychological side. In their research, Zhang \& Ma (2020) stated that $52.1 \%$ of study participants felt horrified and anxious because of the COVID-19 pandemic. Participants' overall scores indicated the impact of mild stress. One possible reason for this finding is that disease outbreaks were not considered severe when the study was conducted. In addition, participants may still be uninformed about the severity of the virus.

Research shows that significant life events cause psychological stress, notable events (such as a significant life change or death of a family member) are closely related to illness (Kangxing et al., 2020). COVID-19 has become a pandemic disease, and now more than 6.66 million patients are confirmed infected and have 402,855 deaths worldwide.

Both men and women who experienced changes in income due to disasters and had health complaints were associated with psychological stress. Household income from sources other than salary and rarely leaving home is associated with psychological stress in women. In contrast, young age, unemployment or job seeker status, and no informational support are associated with psychological stress in men (Ishiguro et al., 2019).

The COVID-19 pandemic as an external stressor can be a threat to family resilience. Walsh (1996 in Uyun 2020) defines family resilience as the ability of the 
family to adapt and survive dynamically changing conditions and have a positive attitude towards existing challenges.

Uyun (2020) states three aspects of family resilience: physical resilience, social resilience, and psychological resilience. The aspect of physical resilience is related to the fulfilment of human physical needs such as food, clothing, housing and health. Losing a job or decreasing income during the pandemic will significantly affect the fulfilment of basic needs and family health. In addition, it can cause family stability to be disturbed. Losing a job can be emotionally exhausting, especially when things are full of uncertainty that can cause stress (Uyun, 2020). According to Child and Family Psychologist Anna Surti Ariani, it will affect all other family members when one family member is sick during this pandemic. The impact can be stress that results in anger in a spouse or child. Such circumstances can make the family situation uncomfortable (Kurniawan, 2020).

Aspects of social resilience are related to relationships between individuals oriented to religious values, effective communication and high commitment in the family (Uyun, 2020). Pusparini (in Safitri, 2020) stated that during the COVID-19 pandemic, there was an increase in domestic violence (KDRT). One reason is that family members meet too often, and the lack of positive communication between family members, making them vulnerable to conflict. Takariawan (in Husna, 2020) said that the family had maintained a balance with time of togetherness and time of separateness so far. These two times form harmony in the family, but the pandemic makes family members spend more time at home to reduce separation (separateness). Pusparini said that many families encounter conflict when they are together too often, even though, ideally, quarantine can strengthen relations between family members (Safitri, 2020).
Aspects of psychological resilience include the ability to overcome nonphysical problems, control emotions positively, positive self-concept, and concern among family members (Uyun, 2020). Uncontrolled changes such as decreased income can affect individual emotional control. Individuals who have low emotional control tend to vent their anger on their partners in the form of verbal and physical violence. Conditions like this can cause stress to children and partners (Safitri, 2020).

The non-fulfilment of the three aspects of family resilience during the pandemic can be a burden that causes stress to family members and possibly causes the quality of marriages to be low. The pandemic causes many changes in people's lives in various aspects that also affect family life. This study was conducted to find out the effect of stress on marriage quality during the COVID-19 pandemic.

\section{Methods}

\section{Participants}

This study took a sample of 242 married people in Denpasar, consisting of 115 men and 127 women. With age distribution as follows: $21-30$ years old $=32$ people $(13 \%)$; $31-40$ years old $=79$ people $(33 \%)$; $41-50$ years old $=72$ people $(30 \%)$; $51-60$ years old $=55$ people $(23 \%) ; 60+$ years $=4$ people $(2 \%)$. Distribution based on the age of marriage as follows: $5-10$ years $=83$ people $(34 \%) ; 11-20$ years $=70$ people $(29 \%) ; 21-30=67$ people $(28 \%) ; 31-40$ years $=22$ people $(9 \%)$.

\section{Data Collection and Instruments}

The data collection technique chosen to find data in this study is a questionnaire. Data collection uses the Marriage Quality Scale, consisting of 32 statements and the COVID Stress Scale, which consists of 38 statements.

The validity test used in this study is content validity by expert judgment. A trial 
was conducted on 242 married people in Denpasar. Based on the item selection results, there were no items that needed to be dropped, so 38 items on the COVID Stress Scale were obtained consisting of 5 dimensions, namely: danger and contamination, Socioeconomic consequences, xenophobia, compulsive checking and reassurance-seeking, and traumatic stress symptoms about COVID19. The Marriage Quality Scale consists of 2 dimensions, namely relations and welfare.

Sugiyono (2015) states that research instruments can be reliable if the instruments used to measure the same object can produce the same data when done repeatedly. Reliability test using Cronbach's alpha formula. The results obtained for the reliability of the COVID Stress Scale of 0.934 and the Marriage Quality Scale of 0.899 .

\section{Data Analysis}

The data were analyzed through 3steps: descriptive analysis, assumption check, and hypothesis testing.

Descriptive Analysis

Descriptive analysis is a data analysis technique that aims to describe or describe data (Setiawati, 2017). The categories of data that have been collected will be converted into interval data using the formula:

Table 1. Categorization

\begin{tabular}{|l|l|}
\hline \multicolumn{1}{|c|}{ Categoy } & \multicolumn{1}{c|}{ Formula } \\
\hline Very High & $\mathrm{X}>\mu+1,5 \sigma$ \\
\hline High & $\mu+0,5 \sigma<\mathrm{X} \leq \mu+1,5 \sigma$ \\
\hline Medium & $\mu-0,5 \sigma<\mathrm{X} \leq \mu+0,5 \sigma$ \\
\hline Low & $\mu-1,5 \sigma<\mathrm{X} \leq \mu-0,5 \sigma$ \\
\hline Very Low & $\mathrm{X} \leq \mu-1,5 \sigma$ \\
\hline
\end{tabular}

$\mu$ : hypothetical mean

$\sigma:$ standard deviation

Normality test

According to Setiawati (2017), the normality test is a test of the data to be analyzed, related to the distribution (spread) in the form of a normal curve. The normality test of the data used the Kolmogorov-Sminorv formula with the help of SPSS 24.0. The data can be said to be normally distributed if the significance value is greater than 0.05 (Setiawati, 2017).

Linearity Test

A linearity test is used to determine the linearity of the data, namely, whether two variables have a linear relationship or not. The linearity test in this study uses the help of IBM Statistics SPSS 24.0. Two variables can have a linear relationship if the significance (Deviation for Linearity) is more than 0.05 (Purnomo, 2016).

Hypothesis testing

Hypothesis testing in this study uses simple linear regression analysis. A simple linear regression analysis test aims to predict the effect of one variable on another variable (Setiawati, 2017).

\section{Findings}

The following are the results of the descriptive analysis in the form of categorization of COVID stress variables and marital quality variables:

1. COVID Stress Variables

Table 2. Categorization of COVID-19 Stress

\begin{tabular}{|l|l|l|}
\hline Categoy & Frequency & Percentage \\
\hline Very High & 0 & $0 \%$ \\
\hline High & 130 & $54 \%$ \\
\hline Medium & 76 & $31 \%$ \\
\hline Low & 29 & $12 \%$ \\
\hline Very Low & 7 & $3 \%$ \\
\hline
\end{tabular}


2. Marital Quality Variables

Table 3. Categorization of Marriage Quality

\begin{tabular}{|l|l|l|}
\hline Categoy & Frequency & Percentage \\
\hline Very High & 241 & $99,6 \%$ \\
\hline High & 1 & $0,4 \%$ \\
\hline Medium & 0 & $0 \%$ \\
\hline Low & 0 & $0 \%$ \\
\hline Very Low & 0 & $0 \%$ \\
\hline
\end{tabular}

Normality Test Results

Based on the normality test results, a significance value of 0.075 was obtained, which was greater than 0.05 . Following the decision-making basis for the KolmogorovSmirnov normality test, it can be concluded that the data in this study meet the assumption of normality.

Linearity Test Results

The significance value for the COVID stress variable with the marital quality variable was 0.131 , greater than 0.05 or $\mathrm{p}>0.05$. Thus, it can be said that the COVID stress variable and the quality of marriage have a linear relationship.

Hypothesis Test Results

The results of hypothesis testing using linear regression analysis showed a significance value (Sig.) of 0.307 , greater than 0.05. Thus, it can be concluded that there is no effect of COVID stress (X) on marriage quality $(\mathrm{Y})$. The results of the analysis of the COVID Stress dimension with the quality of marriage are obtained as follows:

1. The significance value of the danger and contamination fears dimension is 0.758 ( $p>0.05$ ). It can be concluded that danger and contamination fears do not affect the quality of marriage.

2. The significance value of the dimension of fears about socioeconomic consequences is 0.401 . It can be concluded that fears about socioeconomic consequences do not affect the quality of marriage.

3. The significance value of the xenophobia dimension is 0.755 ( $\mathrm{p}>$ 0.05). It can be concluded that xenophobia does not affect the quality of marriage.

4. The significance value of the traumatic stress symptoms dimension is 0.273 ( $\mathrm{p}$ $>0.05)$. It can be concluded that traumatic stress symptoms do not affect the quality of marriage.

5. The significance value of the compulsive checking and reassurance seeking dimension was obtained at 0.102 ( $p>0.05$ ). It can be concluded that compulsive checking and reassurance seeking does not affect the quality of marriage.

\section{Discussion}

The results of the descriptive analysis showed that the stress felt by the subject tended to be in the high category, as many as 130 people or 54\%. During a pandemic, many people exhibit fear and anxiety-related stress responses, which include: fear of infection, fear of coming into contact with objects or surfaces that may be contaminated, fear of strangers who may carry the infection, fear of the socioeconomic consequences of the pandemic, compulsive checking and seek information about possible pandemicrelated threats, and symptoms of pandemicrelated traumatic stress (Taylor, 2020).

The results of the descriptive analysis showed that more than half of the population sample had stress levels in the high category. These findings are similar to studies from China showing nearly $35 \%$ of the general population experienced moderate to severe levels of stress or anxiety-related symptoms in response to COVID-19 (Qiu et al., 2020; Wang et al., 2020). Another study in Italy showed that as many as $2012(72.8 \%)$ respondents had stress levels in the medium category, 404 
$(14.6 \%)$ were in the high category, and 347 $(12.6 \%)$ were in the very high category (Mazza, 2020 ).

Subjects with high-stress levels tend to feel worried about financial problems and worry if they or those closest to them are infected with the virus. In line with Taylor's research (2017), among various common causes of stress, financial difficulties are closely related to psychological stress in parents. The finding of a high level of stress on the subject was also caused by the weakening of the tourism sector due to decreased foreign tourist arrivals, causing hotels and other tourist attractions to lay off their employees. The Bali Province Manpower and Mineral Resources Office (Disnaker) said that until April 19,124, people had been laid off, and 480 people had been laid off (Riza, 2020).

The descriptive analysis of marital quality showed that almost all subjects had a very high level of marital quality in the category of 239 people, or $99.6 \%$. Meanwhile, in the high category, as many as one people or $0.4 \%$. Marriage quality is a subjective evaluation of a husband or wife on the quality of their marriage, which can be carried out on several aspects: closeness and warmth of relationships, cooperation, respect, and welfare (Nurhayati, 2017). Referring to research conducted by researchers, subjects who have very high and high marital quality tend to have warm relationships, cooperate to face difficulties and respect each other. In addition, those who have a very high and high quality of marriage also show gratitude for their marriage, and they feel peaceful and comfortable living together with their partner.

The strong culture of each couple may influence the high quality of marriage in Balinese society. The life of the Balinese people is very thick with the teachings or moral values of Tat Twam Asi. Tat Twam Asi means you are me, and I am you, which contains the principles: joy and sorrow, mutual love, mutual honing, and mutual care. This teaching contains a philosophy so that fellow humans can empathize with other humans (Adhi, 2016). Tat Twam Asi teaches that as humans, we can love each other or love other humans. This teaching implies that I am you and you are me, so treat others as you would like to be treated yourself. Couples who can empathize and love each other certainly have a high quality of marriage.

High levels of external stress are associated with low levels of relationship satisfaction (Randall \& Bondenmann, 2009; Randall \& Bodenmann, 2017). Ellison et al. (2011) mention that financial conditions and stress, in general, can be associated with poor marital quality. However, there is an interesting finding in this study, namely that although most of the respondents showed a high level of stress, it did not affect marriage quality. On the other hand, most of the subjects' marriage quality was in the very high category, $99.6 \%$.

In their research, Yarber et al. (2020) found that although many individuals experienced stress due to the pandemic, overall marital emotional satisfaction remained the same. Most individuals report an increased sense of teamwork and connection. Overall, more participants agreed that the pandemic had a positive impact on their marriage. $74 \%$ of participants agreed the pandemic strengthened their marriage, and $82 \%$ agreed it made them feel more committed to their marriage. $85 \%$ agree that the pandemic helped them appreciate their partner more, helped them appreciate the good life they had before the pandemic and brought their family together.

The explanation for the findings in this study is that couples have good marital stress management. The management of marital stress is dyadic coping. Dyadic coping is a pattern of interaction between partners to cope with stressful situations (Bodenmann, 2005). Every marriage has problems, and how a married couple solves problems contributes to the marriage 
quality. Couples who experience more significant stress show a decrease in marital happiness. However, problem-solving experiences can increase resilience in the face of subsequent stressors and affect marital adjustment (Neff \& Broady, 2011).

Research conducted by Levesque et al. (2014) mentions that dyadic coping influences marital satisfaction; namely, the support from a partner will make individuals more confident in dealing with perceived stress to feel satisfaction in their marriage. In addition, Nugroho (2019) research also states that the more often dyadic coping is carried out by one or both partners, the higher the level of marital quality. The partner's dyadic coping or social support is significantly associated with high marital quality (Bodenmann, 2006). Bondenmann (2005) states that dyadic coping has two main objectives: reducing the stress of each partner and improving the quality of a relationship.

In addition, the communication factor also plays a role in producing a quality marriage. Communication in marriage has long been found to be a factor that affects the quality of marriage (Fowers, 1998 in Nurhayati, 2019). Communication is an essential aspect in relationships to build positive and close relationships (Fowers \& Olson in Alkhusna \& Wahyuningsih 2007).

There is moral teaching in Balinese society called Tri Kaya Parisudha, which means that humans can think, say and act well. Thus, in communicating with other individuals, it is expected to say good things to create harmony with others (Sentana, 2017). Dewi \& Sudhana (2013) mention that effective communication between husband and wife makes interpersonal relationships good to realize harmony in marriage. Couples who apply Tri Kaya Parisudha's ethical teachings, especially in saying good, are more likely to find harmony in their marriage.

In addition, there are factors of spirituality and religiosity that affect the level of quality of marriage. According to an international survey, Indonesia has the most religious population (Damarjati, 2020). It is undeniable that Balinese people are very thick with religious activities, so that Bali is one of the spiritual tourism destinations because tourists can see Balinese ritual activities almost every day (Budiasih, 2017). Prayer, rituals and religious beliefs can help a person cope when experiencing life's stress because of hope and comfort (Rammohan, Rao \& Subbakrishna, 2002 in Utami, 2012). Istiqomah \& Mukhlis (2015) found that there was a relationship between religiosity and marital satisfaction. Couples with a high level of religiosity will be more satisfied with their marriage (Istiqomah \& Mukhlis, 2015). Most of the subjects in this study felt grateful for their marriage to maintain the quality of their marriage in the high category amidst the stress due to the pandemic.

Free time spent with a partner helps increase closeness and intimacy (Fowers \& Olson in Hepi Wahyuningsih, 2007). According to Johnson (2005), there are many different reasons why couples do or do not participate in leisure activities together. Work problems can also be considered a barrier to joint activities. During the pandemic, many people are laid off from work to have more free time to spend with their partners. Shared leisure time is an essential component of marital satisfaction between couples. Free time allows them to develop common interests and provides opportunities for healthy communication and spending quality time together (Sharaievska, Kim, \& Stodolska, 2013)

Couples who have been in a relationship longer and older tend to have lower levels of conflict (Kamp Dush \& Taylor, 2012) and manage conflict more constructive way than younger couples (Birditt et al., 2010). Subjects in this study had a marriage age of more than or equal to 5 years, sufficient time for marriage adjustment. In the first five years of marriage, individual adjustments and 
expectations before marriage will be tested, and couples will also learn ways to deal with crises or conflicts (Kendhawati \& Purba, 2019). Individuals may know more about their partners through shared problemsolving experiences, mainly how couples usually deal with marital problems and life in general (Delatorre \& Wagner, 2018). The length of marriage age in the subject may help maintain marriage quality in the high category when the situation is stressful.

\section{Conclusion}

Based on the research results, it can be concluded that the COVID stress variable does not significantly affect the quality of marriage in married individuals in Bali. Therefore, although the stress variable in most subjects showed a high category, it did not affect the marital quality variable.

\section{Suggestion}

Based on the research that has been done, the researcher has several suggestions as follows:

1. For couples: implementing marital stress management to maintain the quality of marriage.

2. For government institutions: (a) Conduct counselling, seminars and training classes for married couples and prospective brides, (b) Expand the reach of mental health services by facilitating access, such as holding teleconsultation.

3. For future researchers: (a) Explore or explore other factors that may affect the quality of marriage in Bali. (b) Expanding the range of respondents so that the results obtained more generalize to the population.

\section{References}

Adhi, M.K. (2016). Tat Twam Asi: Adaptasi Nilai Kearifan Lokal dalam Pengentasan Kemiskinan Kultura. Seminar Nasional
Riset Inovatif (Senari) Ke-4 Tahun 2016

AlKhusna \& Wahyuningsih, H. (2007). Kualitas Perkawinan Individu yang Menikah tanpa Pacaran. Psikologika, 24, 133-145

Birditt, K. S., Brown, E., Orbuch, T. L., \& McIlvane, J. M. (2010). Marital conflict behaviors and implications for divorce over 16 years. Journal of Marriage and Family, 72(5), 11881204.doi: 10.1111/j.1741-3737.2010. 00758.x

Bodenmann, G., Pihet, S., \& Kayser, K. (2006). The Relationship Between Dyadic Coping and Marital Quality: A 2-Year Longitudinal Study. Journal of Family Psychology, 20(3), 485-493. 10.1037/0893-3200.20.3.485

Bodenmann, G., Revenson,T., \& Kayser, K. (Eds.). (2005). Couples Coping with Stress: Emerging Perspectives on Dyadic Coping. Washington, DC: APA

Budiasih, M. (2017). Parinisata Spiritual di Bali. IHDN, 70-80.

Clayson, D., \& Frost, T. (1984). Impact of Stress and Locus of Control on the Concept of Self. Psychological Reports, 55(3), 919-926. doi:10.2466/pr0.1984.55.3.919

Damarjati, D. (2020). Survei 34 Negara: Orang Indonesia Paling Religius. Detiknews. Retrieved from: https://news.detik.com/berita/d5109802/survei-34-negara-orangindonesia-paling-religius?single $=1$

Delatorre, M.Z., \& Wagner, A. (2018). Marital Conflict Management of Married Men and Women. Psico-USF, 23(2), 229-240. doi: 10.1590/141382712018230204

Dewi, N. R., \& Sudhana, H. (2013). Hubungan Antara Komunikasi Interpersonal Pasutri dengan Keharmonisan dalam Pernikahan. Jurnal Psikologi Udayana, 1(1), 22-31 
Ellison, C., Henderson, A., Glenn, N., \& Harkrider, K. (2011). Sanctification, Stress, and Marital Quality. Family Relation, 404-420. doi:10.1111/j.17413729.2011.00658.x

Herlanda, B. F. (2017). Hubungan Kualitas Perkawinan dan Intensi Berselingkub pada Pernikahan. Skripsi. Universitas Sanata Dharma

Istiqomah, I., \& Mukhlis. (2015). Hubungan Antara Religiusitas dengan Kepuasan Perkawinan. Jurnal Psikologi, 11(2), 7178

Johnson, H.A. (2005). The Contribution of Couple Leisure Involvement, Leisure Time, and Leisure Satisfaction to Marital Satisfaction. Thesis, Brigham Young University

Kamp Dush, C. M., \& Taylor, M. G. (2012). Trajectories of Marital Conflict Across the Life Course: Predictors and Interactions with Marital Happiness Trajectories. Journal of Family Issues, 33(3), 341-368. doi: 10.1177/0192513X11409684

Kangxing, S., Tao, L., Dan, L., Fengsu, H., Fengying, B., Stratton, T., . . . Yang, J. (2020). Psychological Stress and Gender Differences during COVID19 Pandemic in Chinese Population. medRxiv.

doi:10.1101/2020.04.29.20084061

Kendhawati, L., \& Purba, F.D. (2019). Hubungan Kualitas Pernikahan dengan Kebahagiaan dan Kepuasan Hidup Pribadi: Studi pada Individu dengan Usia Pernikahan di Bawah Lima Tahun di Bandung. Jurnal Psikologi, 18(1), 106-115.

Kurniawan, I. (Mei 2020). Pandemi Corona Menguji Ketahanan Keluarga. Prfmnews-id. Retrieved from: https://prfmnews.pikiranrakyat.com/nasional/pr13383136/pandemi-corona-mengujiketahanan-keluarga?page $=2$

Ledermann, T., Bodenmann, G., Rudaz, M., \& Bradbury, T. (2010). Stress,
Communication, and Marital Quality in Couples. Family Relation, 59(April 2010), 195-206. doi:10.1111/j.17413729.2010.00595.x

Mazza, C., Ricci, E., Biondi, S., Colasanti, M., Ferracuti, S., Napoli, C., Roma, P., (2020). A Nationwide Survey of Psychological Distress among Italian People during The COVID19 Pandemic: Immediate Psychological Responses and Associated Factors. Int. J. Environ. Res. Public Health, 17(9). doi: 10.3390/ijerph17093165.

Nurhayati, S. R., Faturochman, \& Helmi, A. F. (2019) Marital Quality: A Conceptual Review. Buletin Psikologi, 27(2), $109 \quad-\quad 124$. doi:10.22146/buletinpsikologi.37691

Okatarina, L.P., Wijaya, M., \& Demartoto, A. (2015). PEMAKNAAN PERKAWINAN: Studi Kasus pada Perempuan Lajang yang Bekerja di Kecamanatan Bulukerto Kabupaten Wonogiri. Jurnal Analisa Sosiologi, 4(1), 75-90

Qiu, J., Shen, B., Zhao, M., Wang, Z., Xie, B., \& Xu, Y. (2020). A Nationwide Survey of Psychological Distress among Chinese People in the COVID-19 Epidemic: Implications and Policy Recommendations. General Psychiatry. doi: 10.1136/ gpsych-2020100213

Rahmah, A. A., Rahman, A. A., \& Fitriah, E. A. (2017). Prediktor Kualitas Pernikahan: Penyesuaian Pernikahan dan Nilai Personal. Jurnal Psikologi, 13(2), 92-97.

Randall, A., \& Bodenmann, G. (2009). The Role of Stress on Close Relationships and Marital Satisfaction. Clinical Psychology Review, 29(2), 105-115. doi:10.1016/j.cpr.2008.10.004

Randall, A., \& Bodenmann, G. (2017). Stress and Its Associations with Relationship Satisfaction. Current Opinion in Psychology, 13. doi:10.1016/j.copsyc.2016.05.010 
Riza, A. (April 2020). Imbas Corona, 19.124 Karyawan di Bali Dirumahkan dan 480 PHK. Detiknews. Retrieved from: https://news.detik.com/berita/d4968769/imbas-corona-19124karyawan-di-bali-dirumahkan-dan480-phk

Safitri, G.L. (April 2020). Menjaga Ketahanan Keluarga saat Pandemi COVID-19. Pontianakpost. Retrieved from: https://pontianakpost.co.id/menjaga -ketahanan-keluarga-saat-pandemicovid-19/

Sentana, G.D.D. (2017). Penanaman Konsep Tri Kaya Parisudha dalam Tradisi Mareraosan. Jurnal Pendidikan Hindu, 4(2), 33-39. doi: $\underline{10.25078 / \mathrm{gw} . v 4 \mathrm{i} 2.1056}$

Setiawan, F. P., \& Rahmat, I. (2011). Hubungan Status Sosial Ekonomi Keluarga dengan Stres pada Pasangan Usia Muda di Desa Giricahyo Purwosari Gunungkidul. Naskah Publikasi.

Setiawati, F.A. (2017). Statistika Terapan untuk Penelitian Pendidikan dan Sosial. Yogyakarta: Parama Publishing.

Sharaievska, I., Kim, J., \& Stodolska, M. (2013). Leisure and Marital Satisfaction in Intercultural Marriages. Journal of Leisure Research, 45(4), 445-465. doi: 10.18666/jlr2013-v45-i4-3894

Sugiyono. (2015). Metode Penelitian Pendidikan: Pendekatan Kuantitatif. Kualitatif dan RひD. Bandung Alfabeta

Taylor, M., Stevens, G., Agho, K., \& Raphael, B. (2017). The Impacts of Household Financial Stress, Resilience, Social Support, and Other Adversities on the Psychological Distress of Western Sydney Parents. International Journal of Population, 2017, 1-12. doi: 10.1155/2017/6310683

Taylor, S., Landry, C., Paluszek, M., Fergus, T., McKay, D., \& Asmundson, G. (2020). Development and Initial
Validation of the COVID Stress Scales. Journal of Anxiety Disorder, 72, 1-7.

doi:10.1016/j.janxdis.2020.102232

Utami, M.S. (2012). Religiusitas, Koping Religius, dan Kesejahteraan Subjektif. Jurnal Psikologi 39(1), 46-66

Uyun, M. (Mei 2020). Ketahanan Keluarga dan Dampak Psikologis dimasa Pandemi Global. Disampaikan dalam rangka Webinar Program Doktor Psikologi Pendidikan Islam, di Universitas Muhammadiyah Yogyakarta.

Uyun, M. (Mei 2020). Ketahanan Keluarga dan Dampak Psikologis dimasa Pandemi Global. Disampaikan dalam rangka Webinar Program Doktor Psikologi Pendidikan Islam, di Universitas Muhammadiyah Yogyakarta.

Widyaswara, I.W.E \& Sadnyari, I.A.M (Ed). (Desember 2019). Penyebab 884 Kasus Pasangan Cerai di Denpasar 2018, Faktor Ekonomi hingga Liburan, Suami Perlu Tahu. Tribunbali.com. Retrieved from: https://bali.tribunnews.com/2019/1 2/16/penyebab-884-kasus-pasangancerai-di-denpasar-2018-faktorekonomi-hingga-liburan-suami-perlutahu? page $=2$.

Yarber, W., Sanders, S., Milhausen, R.R., Graham, C.A., \& Vanterpool, K., Kennedy, M., Kinsey Institue's Researches. (2020). Impact of the COVID-19 Pandemic on Marital Quality. Disampaikan dalam pertemuan tahunan Society for the Scientific Study of Sexuality

Zhang, Y., \& Ma, Z. F. (2020). Impact of the COVID-19 Pandemic on Mental Health and Quality of Life among Local Residents in Liaoning Province, China: A Cross-Sectional Study. International Journal of Environmental Research and Public Health, 17(7). doi:10.3390/ijerph17072381 